\title{
LOGISTIC ASPECTS OF THE NATO COMPREHENSIVE APPROACH TO THE CONDUCT OF OPERATIONS: ORCHESTRATING THE ENGAGEMENT OF MILITARY LOGISTICS RESOURCES AND CAPABILITIES IN STABILITY AND HUMANITARIAN OPERATIONS
}

\author{
Andrzej Lis
}

Nicolaus Copernicus University in Torun,

The Faculty of Economic Sciences and Management, Toruń, Poland

e-mail: andrzejlis@econ.umk.pl

\begin{abstract}
Research purpose: The aim of the paper is to analyse the logistic aspects of the military comprehensive approach to the conduct of operations. First of all, the assumptions of the NATO comprehensive approach are studied. Secondly, the role of military logistics in the comprehensive approach is discussed. Thirdly, the requirements of effective management and coordination between military logistics and civilian organisations during stability operations are identified.

Methodology/approach: The research methods include the analysis of literature and official military publications such as: doctrines, handbooks and NATO summits declarations. The study encompasses military publications issued by NATO, the United States and the United Kingdom.

Findings: The idea of the comprehensive approach is to combine and coordinate the efforts of military and civilian organisations within the area of the crisis management operation for the success of this operation. There are three possible roles played by military logistics within the frame of the comprehensive approach: (1) military resources and capabilities may be applied to support civilians during stability operations, (2) through contracting military logistics may contribute to the restoration of the local economy, (3) sharing their knowledge, lessons and best practices military logisticians enable international and non-governmental organisations to improve the efficiency and effectiveness of their logistics operations. Comprehensive approach operations should be led by civilians but due to the engagement of the resources and capabilities of military logistics close cooperation and coordination as well as coordinating mechanisms between military logistics and civilian partners are required to be established.
\end{abstract}

Limitations/implications: Official military publications such as: doctrines, handbooks and NATO summits declarations are the manifestations of lessons from operations identified and learned by the military. Nevertheless, the lack of the empirical data collected directly from comprehensive 
LOGISTIC ASPECTS OF THE NATO COMPREHENSIVE

Andrzej Lis approach operations should be considered as an limitation of the study to be improved in further research.

Originality/value: So far, not enough research attention has been given to the issue of the military logistics engagement in the comprehensive approach. Therefore, through exploration of the role of military logistics within the context of the comprehensive approach to operation and the study of its relationships with humanitarian logistics the paper contributes to filling the knowledge gap.

Keywords: comprehensive approach, military logistics, stability operations, humanitarian operations

Paper type: Research paper

\section{Introduction}

Integration is considered to be one of the features of contemporary logistics. Among the variety of levels at which integration of logistics is observed, Blaik (2010) enumerates integration of logistic functions and processes between organisations. Similarly, considering the issues of military logistics integration, Lis (2014) discusses its inter-organisational aspects, including integration between military and civilian logistics. Nevertheless, the studies conducted from the point of view of military logistics focus their attention on integrating civilian resources and management concepts into the military logistic systems (cf. Maj, 2013; Jałowiec and Lis, 2014; Jałowiec, 2013). The abundance of publications on military outsourcing and the contracting function of military logistics (cf. Smyk, 2007; Jałowiec, 2009; Lis, 2009; Jałowiec, 2010; Lis, 2011; Smyk, 2011; Klecha and Lis, 2012; Smyk, 2014) is the manifestation of this trend.

As pointed out in the U.S. Army doctrine publication on sustainment (ADP 4-0, 2012, p. 10) military logistics resources and capabilities may be used during the operations of defence support of civil authorities and stability operations. The engagement of military logistics in the support of civil administrations of their national states may be regulated in military doctrines (e.g. in the USA, cf. JP 3-28, 2013; ADP 3-28, 2012; ADRP 3-28, 2013) or national legal acts (e.g. in Poland). Nevertheless, the attention of the paper is focused on the second of the aforementioned situations i.e. the engagement of military logistics in the support of civilians during stability operations. The aim of the paper is to analyse the logistic aspects of the military comprehensive approach to the conduct of operations. The focus is given to the NATO concept of the comprehensive approach. In order to plan and organise the research process the following questions have been identified: (1) What are the assumptions of the NATO comprehensive approach to the conduct of military operations? (2) What is the role of military logistics in the comprehensive approach? (3) What are the requirements of effective management and coordination between military logistics and civilian organisations during stability operations? The research methods applied to achieve the aforementioned aim of the paper include the analysis of literature and official military publications 
such as: doctrines, handbooks and NATO summits declarations. The study has encompassed military publications issued by NATO, the United States and the United Kingdom. Certainly, due to the unlimited distribution of the paper, exclusively unclassified documents published on official websites have been included into analysis.

\section{Comprehensive approach to the conduct of military operations}

The concept of comprehensive approach, known also as the multidimensional approach or the integrated approach emerged in the early 2000s and has been adopted by numerous international organisations e.g. the European Union (cf. Drent, 2011), NATO, the United Nations, the Organisation for Security and Cooperation in Europe, the African Union, the Organisation for Economic Cooperation and Development and nations such as: France, the United Kingdom, Germany and the United States. The overall idea of the comprehensive approach is to coordinate the efforts of civilian and military actors for the success of crisis management operations (Wendling, 2010). The consensus on the defining of the comprehensive approach has not been achieved yet. Therefore, the variety of definitions is observed in the literature and official publications. Taking into account the military logistics prism applied to the paper and the focus on management and coordination of efforts between military and civilian organisations, the following definition is chosen as a foundation for further discussions: "The Comprehensive Approach is a design process to align incentives among international and local actors to increase resilience in the engagement space while reducing the transaction costs associated with multiple actor interaction in complex operations" (Hallet and Thorngren, 2011). The implementation of the comprehensive approach is driven by seeking the following types of incentives when conducting crisis management operations: efficient use of rare resources, consistent efforts of all engaged organisations, urgency to progress in operations which are stuck in the middle, increasing the level of international security, reducing military losses and establishing legitimacy for operations (Conning and Friis, 2008).

Nowadays, the functions of the armed forces extend beyond the engagement in traditional high intensity warfighting conflicts. For instance, as stated in the NATO joint doctrine, military power may be used in operations aimed at conflict prevention, disaster relief, stabilisation and peace support (AJP-01(D), 2010, p. 1.3). While performing these missions, military commanders encounter an increasing complexity of operational environments. Therefore, in order to respond to such new circumstances, NATO "seeks to achieve its objectives thorough a comprehensive approach that requires effective coordination and cooperation among national governmental departments and agencies, non-governmental organisations (NGOs), international organisations (IOs), and the private sector in 
LOGISTIC ASPECTS OF THE NATO COMPREHENSIVE

Andrzej Lis any alliance or coalition throughout an entire operation" (AJP-3(B), 2011, p. 1.1). The need for a comprehensive approach was confirmed by the lessons learned from the operations in Afghanistan, Libya and Kosovo (AJP-01(D), 2010, p. 2.11; NATO Logistics Handbook, 2012). The role of a comprehensive approach was highlighted in the official declarations of the heads of member states participating in the NATO summits held in Bucharest (2008, para 11), Lisbon (2010, para 8-9) and Chicago (2012, para 18) and Wales (2014, para 99).

NATO doctrines highly value the role of CIMIC (Civil-Military Cooperation) to be a bridge and an interface between military forces and civilians actors in the area of operation. When the aims and objectives of an operation can be achieved without use or threat of use of deadly force, both military and civilian efforts should be combined into a collective strategy. Nevertheless, it should be remembered that in some circumstances, such as a high intensity warfighting scenario, the expectations of civilian organisations and the mission of military forces may be in conflict. However, even in such situations "CIMIC will still be a major consideration because of the need to obtain local resources and facilitate eventual transition to civilian government" (AJP-01(D), 2010, p. 5.5).

The NATO comprehensive approach is implemented at the following levels of management and command: political and strategic levels, an operational level, and a theatre (tactical) level. The aim of comprehensive approach is: to improve the implementation of NATO crisis management procedures; to improve the cooperation with civilian organisations (e.g. the UN, governmental and nongovernmental organisations) within the area of operation and to enhance the use of military capability in the stabilisation and reconstruction phases of operations (AJP-01(D), 2010, pp. 2.11-2.12). The NATO's efforts within the field of the comprehensive approach are focused on the following areas of activity: planning and conducting operations; sharing lessons and enhancing cooperation with civilian partners through training, education and common exercises; developing cooperation relationships with external organisations and public communication (A 'Comprehensive Approach' to Crises, 2014).

In spite of the implementation differences determined by specific conditions of a particular operation and its level (strategic, operational and tactical), the following governing principles of a comprehensive approach should be enumerated: proactive engagement of all actors in the theatre, shared understanding between the parties, outcome-based thinking and collaborative working (AJP01(D), 2010, p. 2.12; AJP-3(B), 2011, pp. 1.1-1.2). The NATO principles of the comprehensive approach are reflected in doctrine publications of its members states (e.g. United Kingdom, cf. JDP 0-01, 2014, pp. 44-45) including logistics doctrines (cf. JDP 4-00, 2015, p. 8).

Summing up, the idea of the comprehensive approach is to combine and 
crisis management operation for the success of this operation. The assumptions of the comprehensive approach derived from the lessons learned from recent operations are confirmed by the official declarations of NATO summits and they are included into doctrinal publications of the Alliance and its member states.

\section{The role of military logistics in the comprehensive approach}

The primary mission of military logistics is to support operational forces. Nevertheless, as observed by Kurasiński (2007), in stability operations led by NATO, the European Union or the United Nations, the scope of beneficiaries of the support provided by the military logistic system may be extended. In some situations, the contribution of military logistic resources and capabilities to a comprehensive approach in the conduct of an operation is required. As stated in the NATO Logistics Handbook (2012):

"[m]ilitary logistic capabilities and stocks as well as logistic C2 [command and control] may be used to support the local population until proper civilian institutions such as Governmental Organisations (GOs), Non-Governmental Organisation (NGOs) or local authorities are able to perform these tasks. This role does not imply only the support to the local population, but it also implies the enabling of civilian institutions to establish themselves in order to be able to deliver the support to the local population for example, support to NGOs and International Organisations (IOs), civilian staff for strategic and tactical support, fuel, medical, food, warehousing and maintenance".

According to the U.S. joint logistics publication (JP-4.0, 2013, pp. IV.7-IV.9) joint operations consist of the following phases: 0 - shape, 1 - deter, 2 - seize the initiative, 3 - dominate, 4 - stabilize, 5 - enable civil authority. From phase 0 to phase 3 military logistics is focused on planning and preparation for the operation, deployment, accessing theatre infrastructure and sustaining operational troops. In phases 4 and 5 the priority is shifted from the support for the military to the needs of civilians. The stabilisation phase "often includes providing basic subsistence to the civilian population [...]. During this phase logistics support frequently expands to meet stabilisation requirements including critical infrastructure repair, base camps for specific purposes, and improved theatre distribution capabilities" (JP4.0, 2013, p. IV.9). In the enabling civil authority phase, besides planning for redeployment and force regeneration, military logistics may be engaged in relief operations and community assistance.

Military logistics commanders should be aware of the fact that in some cases the aims and priorities of the military and civilian organisation with the area of operation may be competitive. Moreover, "[c]ommanders should anticipate NGOs objecting to military actions they perceive as compromising to their impartiality, independence, humanitarianism, or neutrality, principles that NGOs vigorously protect" (ADRP 4-0, 2012, p. 2.13). 
LOGISTIC ASPECTS OF THE NATO COMPREHENSIVE

Andrzej Lis
The role of military logistics in stability operations may be considered from two perspectives. On the one hand, military logistics resources and capabilities may be used for stability tasks including: humanitarian assistance (e.g. food, water, shelter and medical services), supporting local population, conducting demining operations and assisting local authorities to restore their capabilities. On the other hand, military logistics may support local economies and infrastructure development through operational contracting (ADRP 4-0, 2012, p. 3.15). As observed in the U.S. Army sustainment doctrine (ADP 4-0, 2012, p. 10) stability operations are "often sustainment intensive particularly in logistics, financial management, medical and engineering capabilities". Therefore, in some cases military logistics troops may constitute the major part of a military contingent or to be the only forces in the area. Similarly, military logistics may precede the deployment of other forces or stay in the area after the redeployment of the main body of a military contingent (cf. ADRP 4-0, 2012, p. 2.13).

The issue of comprehensive approach is associated with the civil-military cooperation (CIMIC) which is considered to be a related function of military logistics. As observed in the NATO Logistics Handbook (2012), military commanders may be required "to deal with civil tasks and organisations aimed at facilitating the accomplishment of the mission by making civilian resources available to the military as well as military resources available to International Organisations (IOs) and Non-Governmental Organisations (NGOs) in view of military support to a Comprehensive Approach (CA)". According to the U.S. military logistics regulation, a CIMIC centre is the most recommended body to coordinate and orchestrate the military support provided to IOs and NGOs (ADRP 4-0, 2012, p. 2.13).

As officially stated, the Allied Joint Doctrine Publication for Modes of Multinational Logistic Support is applicable to the Comprehensive Approach context (AJP-4.9, 2013, p. 1.1). In consequence, the variety of modes of multinational logistic support may be used to share resources with civilian actors in the area of operations, which includes in particular (AJP-4.9, 2013, p. 1.2):

- "pre-planned mutual support including [Host Nation Support] HNS, [Contractor Support to Operations] CSO, mutual support agreements (MSAs) and cooperation between national support elements (NSEs) that are arranged bi- or multilaterally by NATO and/or nations";

- support and services provided by a Logistic Lead Nation (LLN) or a Logistic Role Specialist Nation (LRSN);

- support and services provided by a Multinational Integrated Logistic Unit (MILU) and a Multinational Integrated Medical Unit (MIMU);

- support and services provided by a Multinational Logistic Unit (MLU) and a Multinational Medical Unit (MMU). 
Besides providing civilian populations with its resources and capabilities and strengthening local economies through operational contracting, military logistics may also support the elements of the humanitarian logistic system through sharing its knowledge and expertise learned from operations and assimilated from business logistics. Moore and Antill (2011) point out many similarities between military logistics and humanitarian logistics, among others differentiating between the requirements in operational and non-operational environments. They claim that "[t]he way that the military has adapted commercial practices in its application of supply chain management could be taken further - into the humanitarian environment - especially in the immediate response to a disaster or crisis (natural of man made)" (Moore and Antill, 2011).

Summing up, there are three possible roles played by military logistics within the frame of the comprehensive approach. Firstly, military resources and capabilities may be applied to support civilians during stability operations. Secondly, through contracting military logistics may contribute to the restoration of the local economy. Thirdly, sharing their knowledge, lessons and best practices military logisticians enable international and non-governmental organisations to improve the efficiency and effectiveness of their logistics operations.

\section{The requirements of effective management and coordination between military logistics and civilian organisations}

NATO acknowledges an important role played by civilian organisations in the theatre of an operation and its responsibility to support the efforts of IOs and NGOs. Simultaneously, NATO clearly defines the principles of the comprehensive approach management:

"Depending on the operation, individual nations and the NATO's agreed role, NATO may make a major contribution within a CA [Comprehensive Approach], but NATO cannot lead this effort. Leadership is clearly the role of the United Nations which has the responsibility for coordinating the necessary international civilian and military aspects of crisis management and peace building in current and future operations. NATO will decide on a case-by-case basis how to support the $\mathrm{CA}$ of the international community and to contribute to potential stabilisation and reconstruction operations, establishing a safe and secure environment as well as freedom of movement for the relevant national authorities and population as well as for other actors" (NATO Logistics Handbook, 2012, p. 57).

As identified by the Multinational Experiment 5, while operating within the frame of the comprehensive approach, military logistics has to cope with the variety of challenges. First of all, the lack of compatibility between the approaches represented by IOs and NGOs is observed which has a negative impact on the effectiveness of managing common efforts. Secondly, participating organisations 
LOGISTIC ASPECTS OF THE NATO COMPREHENSIVE

Andrzej Lis often lack effective methods to measure the progress of their operations which becomes even more harmful while making attempts to coordinate actions. Thirdly, cooperating partners suffer from insufficient information sharing. Finally, there is not enough situational awareness among the parties which makes any collaboration difficult (MNE-5, 2009, p. 9).

The use of military logistics forces and resources for the comprehensive approach requires proper planning and coordination. The operations logistics planning should engage all the stakeholders of the logistic activities in the area of operations, including civilian organisations. Such a cooperation is to be established from the beginning of the planning process (NATO Logistics Handbook, 2012). Therefore, the need of coordination with International Organisations and NonGovernmental Organisations is listed among the key aspects to be considered when conducting operations logistics planning. As recommended in the NATO Logistics Handbook (2012) "[w]ith the implementation of the Comprehensive Approach to the planning process, planning should include, where possible, IOs such as the United Nations (UN), Organisation for Security Cooperation in Europe (OSCE) or the Red Cross and various NGOs such as Médecins sans Frontières".

The NATO joint doctrine sets a requirement of "an efficient and comprehensive liaison structure" to be established between military headquarters and forces and civilian organisations (IOs, NGOs) within the area of operation (AJP01(D), 2010, p. 6.3). Similarly, the NATO doctrine for the conduct of operations highlights the role of interagency coordination, which is particularly important for humanitarian/disaster relief operations (AJP-3(B), 2011, p. 2.11). The importance of coordination of military and civilian logistics efforts during crisis response and limited contingency operations is also pointed out by the the U.S. joint logistics doctrine (JP-4.0, 2013, p. V.2):

"Logisticians must understand multinational and interagency logistics capabilities and coordinate mutual support, integrating them into the joint operation when appropriate. [....] Many crisis response missions such as foreign humanitarian assistance and disaster relief operations, require time-sensitive sourcing of critical commodities and capabilities, and rapid delivery to the point of need".

As a result of the Multinational Experiment 5, the bunch of recommendations has been produced in order to improve the logistics management within the frame of the comprehensive approach. Firstly, an independent civilian logistic advisor is recommended to be nominated. Such a coordinator should be a member of the interagency implementation forum. Secondly, a logistics focus group is proposed to be established under the head of the logistic coordinator. A military logistics representative should be included into this body. It may be necessary to set up one or more coordination centres responsible for particular logistics functions e.g. a movement and transportation coordination centre or an 
HNS coordination centre. Fourthly, the sharing of logistics information should be the priority as it is the key success factor for any effective logistics support. Therefore, overcoming any technological barriers or security regulations restraints to share information is needed (MNE5, 2009, pp. 5, 13-18). The U.S. Army doctrine reference publication on sustainment (ADRP 4-0, 2012, p. 2.13) provides the following recommendations in order to ensure effective cooperation between military logistics and civilian organisations in the theatre: establishing common and unambiguous understanding of the situation; establishing clearly defined "objectives, end state and transition criteria for each involved organisation or agency"; developing common assumptions for the sustainment planning process.

When military logistics participates in the comprehensive approach, the civilian partners may be engaged in planning processes for relevant logistic functions e.g. the HNS planning process. Host Nations Support is one of the modes of the support for military logistics in multinational operations. When agreed with a Host Nation, the HNS framework may be extended to International Organisations in the area of operations. In such a case IOs participate in the HNS planning process and they perform the roles and responsibilities of Sending Nations (SNs). It should be highlighted, that the HNS framework requires complex legal and financial arrangements between a NATO commander, Sending Nations and a Host Nations. "When other federal government agencies, as well as civilian agencies and other organisations in a CA are involved, the legal and financial management challenges are multiplied considerably. [Therefore] where possible, NATO looks to complete pre-operational arrangements so that operations can be executed unhindered" (NATO Logistics Handbook, 2012).

Summing up, despite the engagement of the resources and capabilities of military logistics into the comprehensive approach, such an operation should be led by civilians. The close cooperation and coordination between all the parties involved in the conduct of an operation is necessary to ensure its efficiency and effectiveness. Therefore, there is a need for coordinating mechanisms such as incorporating international and non-governmental organisations into military logistics planning processes or establishing coordinating bodies.

\section{Conclusions}

The paper has been focused on the analysis of the logistic aspects of the military comprehensive approach to the conduct of operations.

First of all, the assumptions of the NATO comprehensive approach to the conduct of military operations have been studied. The comprehensive approach has been defined and the incentives to implement the comprehensive approach have been identified. Then, the aims and the activities within the comprehensive approach have been analysed.
LOGISTIC ASPECTS

OF THE NATO

COMPREHENSIVE

Andrzej Lis 
LOGISTIC ASPECTS OF THE NATO COMPREHENSIVE
Andrzej Lis

Secondly, the role of military logistics in the comprehensive approach has been discussed. The scope of the potential engagement of military logistics within the comprehensive approach has been outlined. The roles of military logistics in the comprehensive approach have been enumerated.

Thirdly, the requirements of effective management and coordination between military logistics and civilian organisations during stability operations have been identified. The leading role of civilian in managing logistic support in crisis management operations has been emphasized. The challenges for effective cooperation and coordination between military and civilian logistics have been pointed out. The mechanisms coordinating the efforts of military and civilian logisticians have been discussed.

Summing up, it should be highlighted that logistics is the branch of the armed forces of particular importance for the success of the comprehensive approach and in consequence for the success of any crisis management operation. The most challenging aspect of the engagement of military logistics into the comprehensive approach is the coordination of efforts with civilian partners. Nevertheless, such concerted civil-military efforts are the prerequisite of efficient and effective logistics activities during a crisis management operation.

\section{References}

Blaik, P. (2010), Logistyka: Koncepcja zintegrowanego zarzadzania, Polskie Wydawnictwo Ekonomiczne, Warszawa.

Coning, de C., Friis, K. (2008), "Introduction: How to Conceptualise 'Comprehensive Approach"”, in: Friis, K., Jarmyr, P. (Eds.), Comprehensive Approach: Challenges and Opportunities in Complex Crisis Management, Norsk Utenrikspolitik Institutt, Oslo, pp. 2-9.

Drent, M. (2011), “The EU's Comprehensive Approach to Security: A Culture of Coordination", Studia Diplomatica, Vol. LXIV No. 2, pp. 3-18.

Hallet, M., Thorngren, O. (2011), "Attempting a Comprehensive Approach Definition and its Implications for Reconceptualizing Capability Development", in: Neal, D. J., Wells, I. L. (Eds.), Capability Development in Support of Comprehensive Approaches, National Defense University, Washington, pp. 35-50.

Jałowiec, T. (2009), "Firmy zewnętrzne w zabezpieczeniu logistycznym armii amerykańskiej”, Kwartalnik Bellona, No. 2, pp. 179-183.

Jałowiec, T. (2010), "Firmy w brytyjskich Siłach Zbrojnych”, Przegląd Logistyczny, No. 1, pp. 62-65.

Jałowiec, T. (2013), Współczesne koncepcje i metody zarządzania w logistyce wojskowej: Analiza, ocena i propozycje dla Sit Zbrojnych Rzeczypospolitej Polskiej, Akademia Obrony Narodowej, Warszawa.

Jałowiec, T., Lis, A. (2014), "Integrating Civilian Logistics into the Military Logistic System”, in: Jałowiec, T., Nyszk, W., Smyk, S. (Eds.), Integration in Military Logistics, National Defence University, Warsaw, pp. 18-30.

24 - Klecha, R., Lis, A. (2012), "Wykorzystanie outsourcingu w siłach zbrojnych: Wybrane 
problemy teoretyczne i wyzwania praktycznej implementacji systemu kontraktowania usług zewnętrznych", Zeszyty Naukowe Akademii Obrony Narodowej, No. 1(86), pp. $157-185$.

Kurasiński, Z. (2007), “Zabezpieczenie logistyczne wojsk w operacjach prowadzonych poza obszarem kraju, Logistyka i Transport, No. 1, pp. 43-62.

Lis, A. (2009), "Perspektywy i uwarunkowania rozwoju outsourcingu usług dla sił zbrojnych w Polsce", in: Nalepka, A., Ujwary-Gil, A. (Eds.), Organizacje komercyjne i niekomercyjne wobec wzmożonej konkurencji oraz wzrastających wymagań konsumentów, Wyższa Szkoła Biznesu - National Louis University, Nowy Sącz, pp. 255-264.

Lis, A. (2011), "Military Outsourcing in Poland: Lessons Learned and Prospects for Further Development", in: Nalepka, A., Ujwary-Gil, A. (Eds.), Business and Non-profit Organizations Facing Increased Competition and Growing Customers' Demands, Wyższa Szkoła Biznesu - National Louis University, Nowy Sącz, pp. 124-149.

Lis, A. (2014), "Wymiar organizacyjny integracji w logistyce wojskowej”, in: Nyszk, W., Smyk, S. (Eds.), Integracja w logistyce wojskowej, Akademia Obrony Narodowej, Warszawa, pp. 11-25.

Maj, J. (2013), "Logistyka wojskowa i logistyka cywilna - ich miejsce i rola we współczesnych operacjach militarnych", Systemy Logistyczne Wojsk, No. 39, pp. $153-170$.

Moore, D. M., Antill, P. D. (2011), "The Comprehensive Approach to Humanitarian Logistics: An Opportunity to Enhance Professional Performance?", in: Neal, D. J., Wells I. L., Capability Development in Support of Comprehensive Approaches, National Defense University, Washington, pp. 245-262.

Smyk, S. (2007), Rola zewnętrznych oferentów usług logistycznych (outsourcingu) w logistyce wojskowej, Akademia Obrony Narodowej, Warszawa.

Smyk, S. (2011), Outsourcing usług w systemie logistycznym Sit Zbrojnych Rzeczypospolitej Polskiej, Akademia Obrony Narodowej, Warszawa.

Smyk, S. (2014), "Logistics Outsourcing as a Tool of Military Logistics Processes Integration", in: Jałowiec, T., Nyszk, W., Smyk, S. (Eds.), Integration in Military Logistics, National Defence University, Warsaw, pp. 65-76.

Wendling, C. (2010), The Comprehensive Approach to Civil-Military Crisis Management: A Critical Analysis and Perspective, Institut de Recherche Stratégique de l'Ecole Militaire, Paris.

\section{Military doctrines and publications}

ADP 3-28 (2012), Defense Support of Civil Authorities, Headquarters Department of the Army, Washington, available at: http://armypubs.army.mil/doctrine/DR_pubs/dr_a/ pdf/adp3_28.pdf (accessed 4 August 2015).

ADP 4-0 (2012), Sustainment, Headquarters Department of the Army, Washington, available at: http://armypubs.army.mil/doctrine/DR_pubs/dr_a/pdf/adp4_0.pdf (accessed 4 August 2015).

ADRP 3-28 (2013), Defense Support of Civil Authorities, Headquarters Department of the Army, Washington, available at: http://armypubs.army.mil/doctrine/DR_pubs/dr_a/ pdf/adrp3_28.pdf (accessed 4 August 2015).
LOGISTIC ASPECTS

OF THE NATO

COMPREHENSIVE

Andrzej Lis 
LOGISTIC ASPECTS OF THE NATO COMPREHENSIVE

Andrzej Lis
ADRP 4-0 (2012), Sustainment, Headquarters Department of the Army, Washington, available at: http://armypubs.army.mil/doctrine/DR_pubs/dr_a/pdf/adrp4_0.pdf (accessed 4 August 2015).

AJP-01(D) (2010), Allied Joint Doctrine, NATO Standardization Agency, Brussels, available at: http://nso.nato.int/nso/zPublic/ap/ajp-01(d).pdf (accessed 2 August 2015).

AJP-3(B) (2011), Allied Joint Doctrine for the Conduct of Operations, NATO Standardization Agency, Brussels, available at: http://nso.nato.int/nso/zPublic/ap/ajp-3(b).pdf (accessed 2 August 2015).

AJP-4.9 (2013), Allied Joint Doctrine Publication for Modes of Multinational Logistic Support. Edition A, Version 1, NATO Standardization Agency, Brussels, available at: http://nsa.nato.int/nsa/zPublic/ap/ajp-4.9\%20eda\%20v1\%20e.pdf (accessed 26 April 2014).

JDP 0-01 (2014), UK Defence Doctrine, The Development, Concepts and Doctrine Centre, Swindon, available at: https://www.gov.uk/government/uploads/system/uploads/ attachment_data/file/389755/20141208-JDP_0_01_Ed_5_UK_Defence_Doctrine.pdf (accessed 4 August 2015).

JDP 4-00 (2015), Logistics for Joint Operations, The Development, Concepts and Doctrine Centre, Swindon, available at: https://www.gov.uk/government/uploads/system/ uploads/attachment_data/file/447953/20150721-DCDC_JDP_4_00_Ed_4_Logistics. pdf (accessed 4 August 2015).

JP 3-28 (2013), Defense Support of Civil Authorities, U.S. Joint Staff, available at: http:// www.dtic.mil/doctrine/new_pubs/jp3_28.pdf (accessed 4 August 2015).

JP 4-0 (2013), Joint Logistics, U.S. Joint Staff, available at: http://www.dtic.mil/doctrine/ new_pubs/jp4_0.pdf (accessed 3 August 2015).

NATO Logistics Handbook (2012), NATO Headquarters, Brussels, available at: http:// www.nato.int/docu/logi-en/logistics_hndbk_2012-en.pdf (accessed 22 May 2016).

\section{Other official military publications}

A 'Comprehensive Approach' to Crises (2014), available at: http://www.nato.int/cps/en/ natolive/topics_51633.htm (accessed 3 August 2015).

Bucharest Summit Declaration (2008), available at: http://www.nato.int/cps/en/natolive/ official_texts_8443.htm (accessed 23 November 2014).

Chicago Summit Declaration (2012), available at: http://www.nato.int/cps/en/natohq/ official_texts_87593.htm (accessed 23 November 2014).

Lisbon Summit Declaration (2010), available at: http://www.nato.int/cps/en/natolive/ official_texts_68828.htm (accessed 23 November 2014).

MNE-5 (2009), A Guide to Multinational Logistics within the Comprehensive Approach, USJFCOM J9, Suffolk, available at: http://www.dtic.mil/dtic/tr/fulltext/u2/a588920. pdf (accessed 16 August 2015).

Wales Summit Declaration (2014) , available at: http://www.nato.int/cps/en/natohq/ official_texts_112964.htm (accessed 23 November 2014). 